\title{
Scope and mechanism of the highly stereoselective metal-mediated domino aldol reactions of enolates with aldehydes
}

\author{
M. Emin Cinar ${ }^{*}$, Bernward Engelen, Martin Panthöfer, Hans-Jörg Deiseroth, Jens Schlirf \\ and Michael Schmittel ${ }^{*}$
}

Open Access

\author{
Full Research Paper \\ Address: \\ Department Chemie-Biologie, OC1, Universität Siegen, \\ Adolf-Reichwein-Str., D-57068 Siegen, Germany

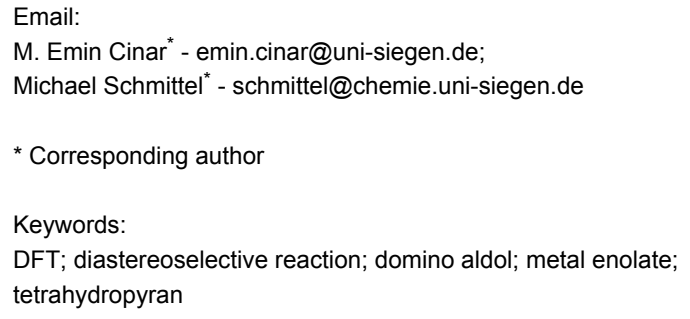

Beilstein J. Org. Chem. 2016, 12, 813-824. doi:10.3762/bjoc. 12.80

Received: 17 November 2015

Accepted: 05 April 2016

Published: 27 April 2016

Associate Editor: S. Bräse

(c) 2016 Cinar et al; licensee Beilstein-Institut. License and terms: see end of document.

\begin{abstract}
A one-pot transformation, which involves the reaction of ketones with aldehydes in the presence of metal halides to furnish tetrahydro- $2 \mathrm{H}$-pyran-2,4-diols in a highly diastereoselective manner, is investigated thoroughly by experiments and computations. The reaction was also successfully implemented on a flow micro reactor system.
\end{abstract}

\section{Introduction}

Since its discovery in the late nineteenth century the aldol reaction has become one of the most powerful tools in the field of carbon-carbon bond formation [1-5]. It is widely used in the formation of many natural products [6-11], stereoselective syntheses [12-16], and tandem reactions [17-19]. While the latter processes usually comprise only one aldol reaction, tandem reaction sequences containing two consecutive aldol steps are mostly limited to the trimerization of enolates [20-22].

Metal enolates (Ti [23], Zr [24], Si [25], and Sn [26]) and boron enolates [27] have adopted a considerable significance because of their high potential to control the stereochemical outcome of the bond formation [28-30]. However, the other group III metal enolates have been almost completely omitted over the years [31]. We have already reported a domino aldol-aldol-hemiacetal process that furnishes racemic tetrahydro- $2 \mathrm{H}$-pyran-2,4diols in a highly stereoselective manner (Scheme 1) [30-37].

In this paper, the domino aldol-aldol-hemiacetal reaction involving several metals ( $\mathrm{Al}, \mathrm{Ga}, \mathrm{In}, \mathrm{Ti}, \mathrm{Zr}, \mathrm{Sn}$ ), and various aldehydes and ketones is studied experimentally and computationally. 


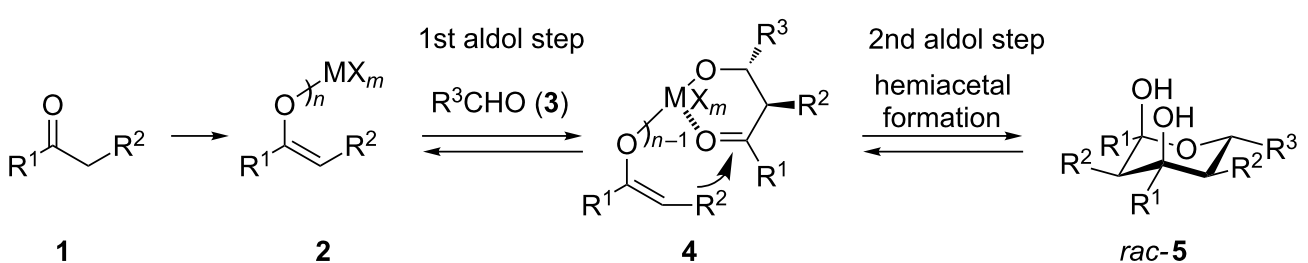

$\mathrm{M}=\mathrm{Al}, \mathrm{Ga}, \mathrm{In}, \mathrm{Ti}, \mathrm{Zr}, \mathrm{Sn}(\mathrm{IV}), \mathrm{La}, \mathrm{Ce}, \mathrm{Sc}$ $n=2,3$ or 4

Scheme 1: Synthesis of racemic tetrahydro-2H-pyran-2,4-diols rac-5 from enolates 2 and aldehydes 3.

\section{Results}

\section{Metal effect}

The experiments were performed to screen suitable metal fragments for their ability to promote the domino aldol reaction by studying the reaction between propiophenone (1a) and benzaldehyde (3a: $\mathrm{Ar}=\mathrm{Ph})($ Scheme 2$)$. The enolate was generated from propiophenone by deprotonation with lithium diisopropylamide (LDA) at $-40{ }^{\circ} \mathrm{C}$ in tetrahydrofuran (THF) and was subsequently reacted with 0.33 equivalents of $\mathrm{MCl}_{3}$ or 0.25 equivalents of $\mathrm{MCl}_{4}$, respectively. The resulting metal enolate was then treated with a stoichiometric amount of benzaldehyde (3a) and stirred for $2 \mathrm{~h}$ at $0{ }^{\circ} \mathrm{C}$, room temperature or $67{ }^{\circ} \mathrm{C}$. The hemiacetal $5 \mathbf{a}$ was obtained in varying yields along with some amount of the monoaldol 6a $[38,39]$ (obtained as a mixture of two diastereomers; syn/anti $\approx 1: 1$ ) and condensation product 6ac (Scheme 2, Table 1).

Aside of the ions mentioned in Table 1 the metal-mediated domino aldol reaction was also probed with $\mathrm{LaCl}_{3}, \mathrm{La}(\mathrm{OTf})_{3}$, $\mathrm{CeCl}_{3}, \mathrm{Sc}(\mathrm{OTf})_{3}, \mathrm{BF}_{3}$ and $\mathrm{SnCl}_{2}$ resulting in failure. While $\mathrm{SnCl}_{2}$ afforded $\mathbf{6 a}$ in $90 \%$ yield, $\mathrm{LaCl}_{3}, \mathrm{La}(\mathrm{OTf})_{3}, \mathrm{CeCl}_{3}$, and
$\mathrm{Sc}(\mathrm{OTf})_{3}$ furnished $6 \mathrm{a}$ in 25, 52, 10 and 55\% yield, respectively. In almost all cases the mono aldolate $6 \mathbf{a}$ was the main product at lower temperatures, e.g., at $0{ }^{\circ} \mathrm{C}$, along with the domino aldol product $5 \mathrm{a}$ obtained in the range of $7-26 \%$ yield.

Higher yields of $5 \mathbf{a}$ were obtained at $0{ }^{\circ} \mathrm{C}$ in the presence of In and $\mathrm{Zr}$. Interestingly, in the case of gallium at $0{ }^{\circ} \mathrm{C}$ and $\mathrm{Sn}(\mathrm{IV})$ at $25^{\circ} \mathrm{C}$ a diastereomer of $\mathbf{5 a}$ also formed in 20 and $29 \%$ yields, respectively. Generally, with nearly all metals, the yield of $\mathbf{5 a}$ increased dramatically when the temperature was raised to $25{ }^{\circ} \mathrm{C}$, but dropped at higher temperatures. The decreased yield at $67{ }^{\circ} \mathrm{C}$ may emerge from the irreversible formation of the aldol condensation product 6ac, which is obtained in $73 \%$ yield in presence of $\mathrm{AlCl}_{3}$, on expense of $\mathbf{5 a}$.

The X-ray structure of racemic 5a (from ethanol) could not be solved due to the presence of a solid racemate in the orthorhombic space group $P 22_{1} 2_{1}$ (no. 19). Three axial hydroxy groups, whose probability of allocation at $\mathrm{C} 2$ and $\mathrm{C} 6$ is 0.5 , respectively, appear to be attached to the pyran ring. This can easily be explained by the superposition of two enantiomers which are

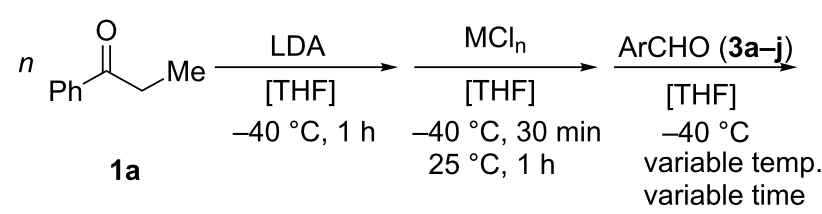

$\mathrm{M}=\mathrm{Al}, \mathrm{Ga}, \mathrm{In}, \mathrm{Ti}, \mathrm{Zr}, \mathrm{Sn}(\mathrm{IV}), \mathrm{La}, \mathrm{Ce}, \mathrm{Sc}$ $n=2,3,4$ or 6

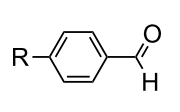

$\begin{array}{ll}\text { 3a: } R=H & 3 d: R=O M e \\ \text { 3b: } R=\mathrm{NMe}_{2} & \text { 3e: } R=\mathrm{NO}_{2} \\ \text { 3c: } R=F & 3 g: R=M e\end{array}$

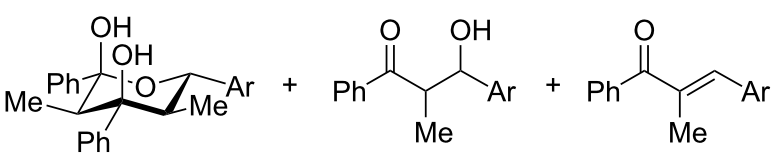

rac-5a-i

$6 a-i$

Scheme 2: Synthesis of rac-5a-j and monoaldol products $\mathbf{6 a - i}$ and $\mathbf{6 a c - i c}$ as obtained from propiophenone (1a) in the presence of metal chloride and substituted arylaldehydes. 
Table 1: Effect of metals on the domino aldol reaction of $1 \mathrm{a}$ and $\mathbf{3 a}$ at different temperatures (reaction time: $2 \mathrm{~h}$ ) on the yield of $\mathbf{5 a}$ and $\mathbf{6 a}$.

\begin{tabular}{|c|c|c|c|c|c|c|c|}
\hline \multirow{3}{*}{ Entry } & \multirow{3}{*}{ Metal } & \multicolumn{6}{|c|}{ Yield of $\mathbf{5 a}$ and $\mathbf{6} \mathbf{a}$ at various temperatures } \\
\hline & & \multicolumn{2}{|l|}{ at $0^{\circ} \mathrm{C}$} & \multicolumn{2}{|l|}{ at $25^{\circ} \mathrm{C}$} & \multicolumn{2}{|l|}{ at $67^{\circ} \mathrm{C}$} \\
\hline & & $5 a(\%)$ & $\mathbf{6 a}(\%)$ & $5 a(\%)$ & $\mathbf{6 a}(\%)$ & $5 \mathbf{a}(\%)$ & $6 a(\%)$ \\
\hline 1 & $\mathrm{Al}$ & 18 & 19 & $64^{a}$ & 8 & 8 & - \\
\hline 2 & $\mathrm{Ga}$ & $17(+20)^{b}$ & 22 & 70 & 19 & 67 & - \\
\hline 3 & $\ln$ & 76 & 3 & $85^{a}$ & 13 & 60 & 2 \\
\hline 4 & $\mathrm{Ti}^{\mathrm{b}}$ & 19 & 26 & 38 & 14 & $50^{a}$ & 5 \\
\hline 5 & $\mathrm{Zr}$ & 61 & 10 & $76^{c}$ & 23 & 21 & - \\
\hline 6 & $\mathrm{Sn}(\mathrm{IV})$ & 7 & 20 & $36(+29)^{b, c}$ & 22 & 17 & 5 \\
\hline
\end{tabular}

aRef. [34]. ${ }^{\mathrm{b}} \mathrm{A}$ diastereomer of 5a. ${ }^{\mathrm{c}}$ Ref. [37].

statistically and isoconformationally incorporated in the crystal lattice. Separation of two enantiomers was achieved by using chiral column chromatography (Chiralpak AD, Daicel) followed by recrystallization from $\mathrm{H}_{2} \mathrm{O} / \mathrm{MeOH}$ (1:4) providing the appropriate crystal for X-ray analysis. Accordingly, the enantiopure crystal of 5a was unambiguously assigned to a tetrahydro-2H-pyran-2,4-diol structure with all phenyl and methyl groups occupying equatorial positions while the hydroxy groups are placed in axial positions with an allocation probability of 1.0 each (Figure 1). Within the crystal lattice the molecules arrange in a chain along the $a$-axis, so that each molecule is twisted by $180^{\circ}$ against each other. Additionally, there are alternating inter- and intramolecular hydrogen bonds between the hydroxy groups.

\section{Mechanistic aspects}

To shed light on the mechanism, the metal to enolate ratio was varied (Table 2), while keeping the optimum temperature for each metal as determined in the previous experiments. The reaction was already successful with two equivalents of enolate per metal fragment. However, higher yields were obtained at higher loadings. For example, zirconium worked best with three enolate units and tin with four. Surprisingly, an excess of an

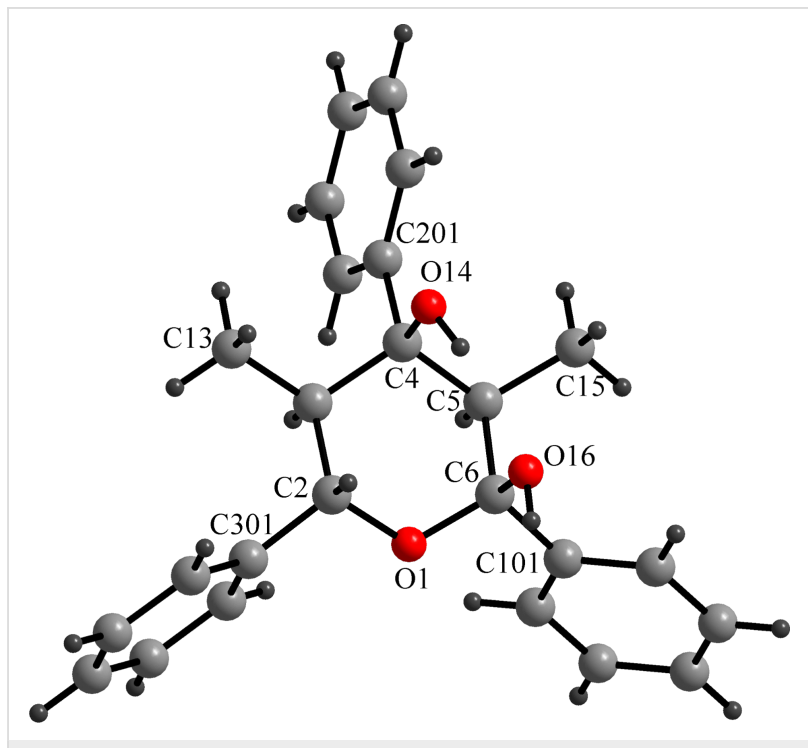

Figure 1: Crystal structure of enantiopure 5a [40].

enolate had different effects on the reactions depending on the metals. While the yield was decreased with zirconium, it increased both with aluminum and indium. In the latter case, $>99 \%$ yield was obtained.

Table 2: Dependence on the stoichiometric amount of propiophenone (1a) enolate with regard to the metal (reaction time: $2 \mathrm{~h}$, reaction temperature: $25^{\circ} \mathrm{C}, 5 \mathrm{a} / 6 \mathrm{a}$ in \%).

\begin{tabular}{|c|c|c|c|c|c|c|c|c|c|}
\hline \multirow{3}{*}{ Entry } & \multirow{3}{*}{$\begin{array}{l}\text { Metal } \\
\text { chloride }\end{array}$} & \multicolumn{8}{|c|}{ Amount of propiophenone (1a) } \\
\hline & & \multicolumn{2}{|c|}{2 equiv } & \multicolumn{2}{|c|}{3 equiv } & \multicolumn{2}{|c|}{4 equiv } & \multicolumn{2}{|c|}{6 equiv } \\
\hline & & $5 a$ & $6 a$ & $5 a$ & $6 a$ & $5 a$ & $6 a$ & $5 a$ & $6 a$ \\
\hline 1 & $\mathrm{ZrCl}_{4}$ & 33 & 48 & 76 & 23 & 68 & 22 & - & - \\
\hline 2 & $\mathrm{SnCl}_{4}$ & 20 & 45 & 14 & 35 & 36 & 22 & - & - \\
\hline 3 & $\mathrm{AlCl}_{3}$ & - & - & 66 & 8 & - & - & 66 & 34 \\
\hline 4 & $\operatorname{lnCl}_{3}$ & - & - & 85 & 13 & - & - & $>99$ & - \\
\hline
\end{tabular}


In the same manner the influence of the amount of aldehyde was examined. As can be seen from the data in Table 3 the ratio of $5 \mathbf{a}$ to $6 \mathbf{a}$ decreases dramatically by increasing the amount of aldehyde two-fold, owing to the formation of higher amounts of the monoaldol product in presence of excess aldehyde (Scheme 2).

In order to check whether this outcome is the result of thermodynamic control, a second aldehyde was added to the reaction mixture after $2 \mathrm{~h}$. The larger the amount of aldehyde in the reaction, the higher is the yield of monoaldol product $\mathbf{6 a}$, which supports a thermodynamically controlled equilibrium as further confirmed by the following observations: (1) with gallium(III) two diastereomeric tetrahydro-2 $\mathrm{H}$-pyran-2,4-diols are formed at $0{ }^{\circ} \mathrm{C}$ and only one (i.e., 5a) at elevated temperature; (2) at higher temperature, the product yield of $\mathbf{5 a}$ is gradually reduced on account of new $6 \mathbf{a c}$ (only in the case of $\mathrm{AlCl}_{3}$ ), which is expected to be formed irreversibly from the metal-bound monoaldolate; (3) when excess benzaldehyde (3a) was added to the reaction with $\mathrm{AlCl}_{3}$, the yield of domino product 5a gradually decreased from, for example, $42 \%$ to $30 \%$ with 1.5 and 2.0 equivalents of benzaldehyde, respectively.

Likewise, the amount of metal chloride influences the yield of 5a. The higher the amount of metal chloride the less likely is the molecular preorganization, which is necessary for the reaction. The reactions carried out with $1.0,0.75$ and 0.5 equivalents of zirconium provided 5a in 76, 42 and 14\% yield, respectively. Reducing the amount to 0.25 equivalents of zirconium furnished only $3 \%$ yield.

Even the concentration influences the yield of 5a. The optimum concentration is $375 \mathrm{mM}$, in which the reaction afforded $76 \%$ yield of $5 \mathrm{a}$. In case of $750 \mathrm{mM}$, the yield decreases drastically to $40 \%$. However, lower concentrations such as $250 \mathrm{mM}$ and $187 \mathrm{mM}$ do not have such an obvious influence and furnish the expected product in 61 and 59\% yields, respectively.

A time dependency study clearly showed that the best yields were achieved after 2 hours and longer reaction times did not lead to improved yields (Table 4).

\section{Variation of enolate and aromatic aldehyde}

Subsequently, various aldehydes were tested in the domino aldol reaction with propiophenone enolate in combination with different metals (Table 5). All aromatic aldehydes, even those containing strongly coordinating substituents such as the dimethylamino group, are accepted in this transformation. With anthracene-9-carbaldehyde (3f), however, the yields drastically

\begin{tabular}{|c|c|c|c|c|c|c|c|c|c|}
\hline \multirow{3}{*}{ Entry } & \multirow{3}{*}{ Metal } & \multicolumn{8}{|c|}{ In presence of benzaldehyde (3a) in } \\
\hline & & \multicolumn{2}{|c|}{1 equiv } & \multicolumn{2}{|c|}{1.5 equiv } & \multicolumn{2}{|c|}{2 equiv } & \multicolumn{2}{|c|}{4 equiv } \\
\hline & & $5 a$ & $6 a$ & $5 a$ & $6 a$ & $5 a$ & $6 a$ & $5 a$ & $6 a$ \\
\hline 1 & $\mathrm{Zr}$ & 65 & 7.0 & 40 & 16 & 19 & 31 & 5 & 60 \\
\hline 2 & $\mathrm{Al}$ & 66 & 8 & 42 & 39 & 30 & 40 & - & - \\
\hline 3 & $\ln$ & 78 & 13 & 53 & 30 & 34 & 42 & - & - \\
\hline
\end{tabular}

\begin{tabular}{|c|c|c|c|c|c|c|c|c|c|c|c|}
\hline \multirow{2}{*}{ Entry } & \multirow{2}{*}{ Time } & \multicolumn{2}{|c|}{$\mathrm{AlCl}_{3}$} & \multicolumn{2}{|c|}{$\mathrm{GaCl}_{3}$} & \multicolumn{2}{|c|}{$\mathrm{InCl}_{3}$} & \multicolumn{2}{|c|}{$\mathrm{ZrCl}_{4}$} & \multicolumn{2}{|l|}{$\mathrm{SnCl}_{4}$} \\
\hline & & $5 a$ & $6 a$ & $5 a$ & $6 a$ & $5 a$ & $6 a$ & $5 a$ & $6 a$ & $5 a$ & $6 a$ \\
\hline 1 & $10 \min$ & 34 & 14 & 15 & 70 & 56 & 9 & 23 & 26 & $15(20)^{a}$ & 40 \\
\hline 2 & $30 \mathrm{~min}$ & 39 & 11 & 22 & 61 & 60 & 10 & 21 & 20 & $21(19)^{a}$ & 18 \\
\hline 3 & $60 \mathrm{~min}$ & 48 & 10 & 42 & 40 & 68 & 10 & 43 & 16 & $34(29)^{a}$ & 17 \\
\hline 4 & $120 \mathrm{~min}$ & 66 & 8 & 70 & 19 & 87 & - & 68 & 22 & $36(29)^{a}$ & 22 \\
\hline 5 & 1 day & - & - & - & - & 73 & 3 & 67 & 6 & - & - \\
\hline 6 & 5 days & - & - & - & - & 75 & 5 & 64 & 5 & - & - \\
\hline
\end{tabular}

asecond diastereomer. 
decreased, most likely due to steric hindrance. Although benzaldehyde (3a) was not used, product 5a appeared in the reaction of anthracene-9-carbaldehyde (3f) with Al and $\mathrm{Zr}$ metals, a finding that requires an explanation (vide infra). The NMR investigations suggest the same relative configuration of $\mathbf{5 b}-\mathbf{j}$ as in $\mathbf{5 a}$ since coupling constants, the shift of the $2-\mathrm{CH}_{3}$ group and the coupling constant $J_{(4-\mathrm{H}, 5-\mathrm{H})}$ agreed.

The facile formation of domino products from aromatic aldehydes proposed to use this reaction also with aromatic dialde-

Table 5: Reactions of various aldehydes with propiophenone metal enolate (reaction time: $2 \mathrm{~h}$, reaction temperature: $25^{\circ} \mathrm{C}$ ).

\begin{tabular}{|c|c|c|c|c|c|c|}
\hline \multirow{2}{*}{ Entry } & \multirow{2}{*}{ Product } & \multirow{2}{*}{ Aldehyde } & \multicolumn{4}{|c|}{ Yield of 5 [\%] } \\
\hline & & & $\mathrm{AlCl}_{3}$ & $\mathrm{InCl}_{3}$ & $\mathrm{SnCl}_{4}$ & $\mathrm{ZrCl}_{4}$ \\
\hline 1 & $5 b$ & & 14 & 47 & 34 & 40 \\
\hline 2 & $5 c$ & & 44 & 94 & 36 & $60^{a}$ \\
\hline 3 & $5 d$ & & 17 & 72 & - & 45 \\
\hline 4 & $5 e$ & & - & 50 & $28^{a}$ & 45 \\
\hline 5 & $5 f$ & & $13^{b}$ & 55 & - & $29^{b}$ \\
\hline 6 & $5 g$ & & - & 62 & - & 66 \\
\hline 7 & $5 h$ & & - & 50 & - & 51 \\
\hline 8 & $5 i$ & & $-^{c}$ & 53 & $-^{c}$ & $-^{c}$ \\
\hline 9 & $5 j^{d}$ & $\mathrm{H}^{\prime}$ & - & 35 & - & 30 \\
\hline 10 & $5 k$ & & - & -e $^{\mathrm{e}}$ & - & $-^{e}$ \\
\hline
\end{tabular}


Table 5: Reactions of various aldehydes with propiophenone metal enolate (reaction time: $2 \mathrm{~h}$, reaction temperature: $25^{\circ} \mathrm{C}$ ). (continued)

11

51

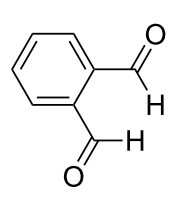

31

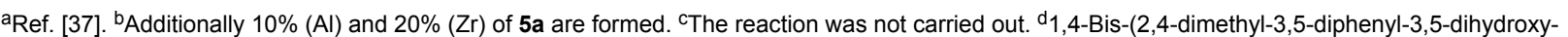
tetrahydropyranyl)-benzene. ${ }^{\mathrm{e}}$ Inseparable mixture. ${ }^{\mathrm{f}}$ No reaction.

hydes $(\mathbf{3} \mathbf{j}-\mathbf{l})$. As anticipated the reaction proceeded smoothly with terephthalaldehyde $(\mathbf{3} \mathbf{j})$ giving rise to product $\mathbf{5} \mathbf{j}$ (see Scheme 2 and Table 5), while isophthalaldehyde (3k) provided a mixture of isomers, which were not separable. The steric congestion in $o$-phthalaldehyde (3I) precluded the formation of the domino-aldol product. However, it is known that $o$-phthalaldehyde (3I) provides the corresponding aldol product in the presence of base [41].

The variability in the ketone moiety proved to be rather restricted (Scheme 3). While in the case of propiophenone (1a) and butyrophenone (1f) moderate to good yields ( $\geq 50 \%)$ were obtained, the reaction with acetophenone (1e) did not furnish any domino aldol product at all. The only acyclic aliphatic ketone that led to the formation of the domino aldol product was pinacolone (1d), which gave the tetrahydro- $2 H$-pyran-2,4-diol 7d in $20 \%$ yield (Scheme 3 , Table 6 ). The reactions of the cyclic ketones were only successful in the case of cyclohexanone (1h), while transformations with five- (1g) and seven(1i) membered rings failed most likely due to strain.

The structure of product $\mathbf{7 h}$, which precipitated from the crude mixture in crystalline form, was solved by single crystal X-ray analysis. The crystals are in the space group $P 2_{1} / c$. It forms "fibers" with alternating incorporation of the two enantiomers of $\mathbf{7 h}$ and they are held together by hydrogen bonds (intramolecular: $1.90 \AA$, intermolecular: $1.93 \AA$ ) (Figure 2).

Various aldehydes were also probed in the domino aldol reaction with the indium enolate of butyrophenone (1f, Scheme 4). Reactions involving 2-furfural, cinnamaldehyde, butyraldehyde, isobutyraldehyde and 2-phenylpropanal did not provide the corresponding tetrahydro- $2 \mathrm{H}$-pyrans, while the reaction with aldehydes possessing $p$ - $\mathrm{NMe}_{2}(\mathbf{3 b}), p-\mathrm{F}(\mathbf{3 c})$ and $p$ - $\mathrm{MeO}(\mathbf{3 d})$ substituted phenyl units worked in reasonable yields affording $8 b-\mathbf{d}$.

The electronic influence of substituents at the aldehyde and/or ketone moiety was more systematically analyzed using series of benzaldehydes (3a, 3c and 3d) and propiophenones (1a-c) both substituted by $\mathrm{H}, \mathrm{OMe}$ and $\mathrm{F}$ at the para-phenyl position. Yields increased with time as expected. The introduction of two $\mathrm{F}$ or $\mathrm{MeO}$ substituents leads to a decrease of the yield compared with 5a (Scheme 5, Table 7). The best yields were obtained within a series in the case of ketone and aldehyde possessing a donor-acceptor situation.

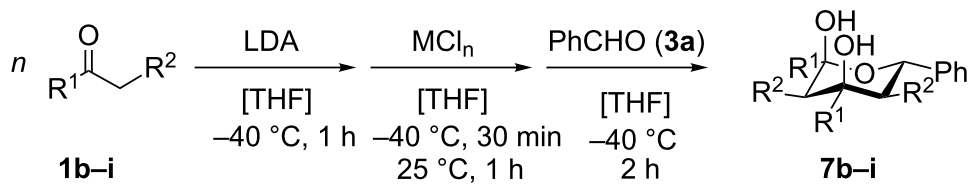

$\mathrm{M}=\ln , \mathrm{Zr}$

$n=3$ or 4

$$
\begin{array}{ll}
\text { 1b: } \mathrm{R}^{1}=p-\mathrm{F}-\mathrm{Ph}, \mathrm{R}^{2}=\mathrm{Me} & \\
\text { 1c: } \mathrm{R}^{1}=p-\mathrm{MeO}-\mathrm{Ph}, \mathrm{R}^{2}=\mathrm{Me} & \\
\text { 1d: } \mathrm{R}^{1}=t-\mathrm{Bu}, \mathrm{R}^{2}=\mathrm{H} & \text { 1g: } n=1 \\
\text { 1e: } \mathrm{R}^{1}=\mathrm{Ph}, \mathrm{R}^{2}=\mathrm{H} & \text { 1h: } n=2 \\
\text { 1f: } \mathrm{R}^{1}=\mathrm{Ph}, \mathrm{R}^{2}=\mathrm{Et} & \text { 1i: } n=3
\end{array}
$$




Table 6: Variation of the ketone in the domino aldol reaction with benzaldehyde (3a) in the presence of $\mathrm{InCl}_{3}$ and $\mathrm{ZrCl}_{4}$ (reaction time: $2 \mathrm{~h}$, reaction
temperature: $25^{\circ} \mathrm{C}$.

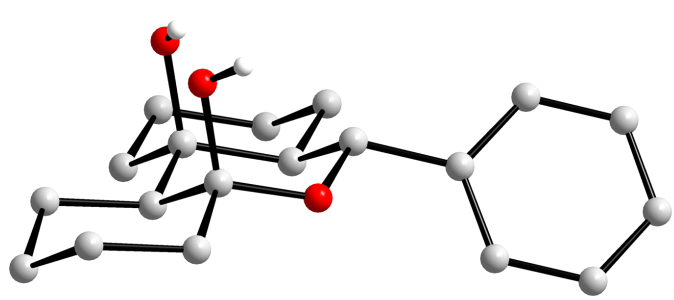

a

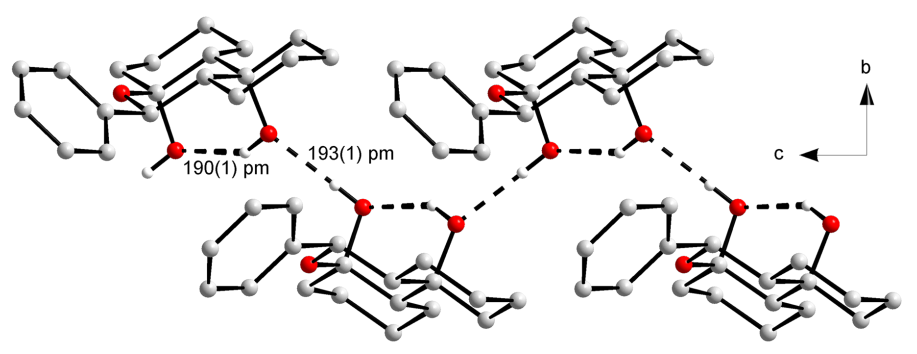

b

Figure 2: (a) Crystal structure of $7 \mathrm{~h}$ and (b) its arrangement in the crystal [43].

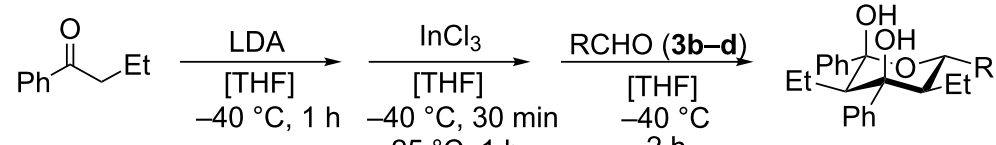

$$
\begin{aligned}
& 1 f \\
& 25^{\circ} \mathrm{C}, 1 \mathrm{~h} \\
& 2 \mathrm{~h}
\end{aligned}
$$

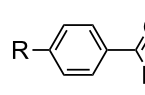

Scheme 4: Reaction of $n$-butyrophenone (1f) with various aldehydes (3b-d) in presence of $\operatorname{InCl}_{3}$ (reaction time: $2 \mathrm{~h}$, reaction temperature: $25^{\circ} \mathrm{C}$ ).

\section{Domino aldol reaction by using a CYTOS ${ }^{\mathrm{TM}}$ microreactor}

Using the CYTOS ${ }^{\mathrm{TM}}$ microreactor, a continuous reactor, the following results were obtained, which are well in agreement with the outcome of the batch experiments. Since a slow flow rate of $1 \mathrm{~mL} \mathrm{~min}^{-1}$ caused precipitation of the compounds and consequently blocking the reactor, flow rates from $2 \mathrm{~mL} \mathrm{~min}^{-1}$ onwards were used to run the reaction (Table 8). The breakdown of the yields with increasing flow rates is easily explained with the short reaction time. 


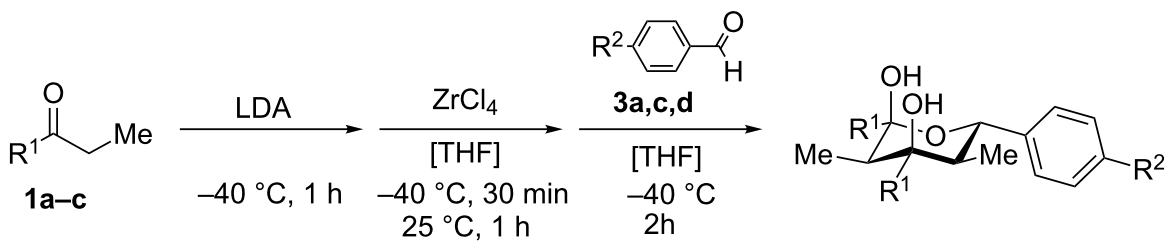
1a: $\mathrm{R}^{1}=\mathrm{Ph}$
1b: $\mathrm{R}^{1}=p-\mathrm{F}-\mathrm{Ph}$
3a: $\mathrm{R}^{2}=\mathrm{H}$
1c: $\mathrm{R}^{1}=p-\mathrm{MeO}-\mathrm{Ph}$
3d: $R^{2}=O M e$

Scheme 5: Domino aldol reactions of different aldehydes and ketones possessing $p-\mathrm{H}, p-\mathrm{F}$ and $p$-MeO substituents at the phenyl units with $\mathrm{ZrCl}$. Products see Table 7.

Table 7: Time dependent domino aldol reactions of different aldehydes and ketones having $\mathrm{H}, \mathrm{F}$ and MeO units at para-position of phenyl units using $\mathrm{ZrCl}_{4}$. Yields are in \% and numbers in brackets are for mono aldol products (reaction time: $2 \mathrm{~h}$, reaction temperature: $25^{\circ} \mathrm{C}$ ).

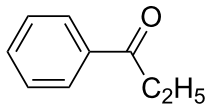

$1 \mathrm{a}$<smiles>CCC(=O)c1ccc(F)cc1</smiles>

$1 \mathrm{~b}$

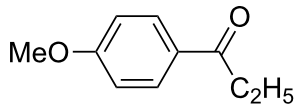

$1 \mathrm{c}$

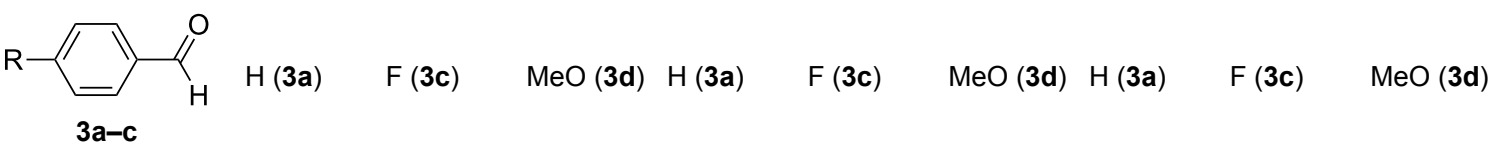

\begin{tabular}{|c|c|c|c|c|c|c|c|c|c|c|}
\hline Entry & Time [min] & $5 a$ & $5 c$ & $5 d$ & $7 a$ & $9 a$ & $9 b$ & $7 b$ & $9 c$ & $9 d$ \\
\hline 1 & 5 & $\begin{array}{l}5 \\
(+10)\end{array}$ & $\begin{array}{l}9 \\
(+9)\end{array}$ & $\begin{array}{l}7 \\
(+12)\end{array}$ & $\begin{array}{l}5 \\
(+15)\end{array}$ & $\begin{array}{l}5 \\
(+18)\end{array}$ & $\begin{array}{l}8 \\
(+14)\end{array}$ & $\begin{array}{l}25 \\
(+7)\end{array}$ & $\begin{array}{l}26 \\
(+11)\end{array}$ & $\begin{array}{l}15 \\
(+19)\end{array}$ \\
\hline 2 & 10 & $\begin{array}{l}8 \\
(+16)\end{array}$ & $\begin{array}{l}23 \\
(+10)\end{array}$ & $\begin{array}{l}10 \\
(+15)\end{array}$ & $\begin{array}{l}6 \\
(+20)\end{array}$ & $\begin{array}{l}8 \\
(+19)\end{array}$ & $\begin{array}{l}10 \\
(+15)\end{array}$ & $\begin{array}{l}28 \\
(+8)\end{array}$ & $\begin{array}{l}26 \\
(+11)\end{array}$ & $\begin{array}{l}17 \\
(+15)\end{array}$ \\
\hline 3 & 20 & $\begin{array}{l}19 \\
(+16)\end{array}$ & $\begin{array}{l}27 \\
(+8)\end{array}$ & $\begin{array}{l}15 \\
(+17)\end{array}$ & $\begin{array}{l}8 \\
(+16)\end{array}$ & $\begin{array}{l}12 \\
(+15)\end{array}$ & $\begin{array}{l}14 \\
(+17)\end{array}$ & $\begin{array}{l}29 \\
(+7)\end{array}$ & $\begin{array}{l}28 \\
(+20)\end{array}$ & $\begin{array}{l}20 \\
(+9)\end{array}$ \\
\hline 4 & 30 & $\begin{array}{l}27 \\
(+18)\end{array}$ & $\begin{array}{l}35 \\
(+10)\end{array}$ & $\begin{array}{l}16 \\
(+16)\end{array}$ & $\begin{array}{l}12 \\
(+16)\end{array}$ & $\begin{array}{l}15 \\
(+19)\end{array}$ & $\begin{array}{l}20 \\
(+16)\end{array}$ & $\begin{array}{l}32 \\
(+12)\end{array}$ & $\begin{array}{l}32 \\
(+12)\end{array}$ & $\begin{array}{l}25 \\
(+11)\end{array}$ \\
\hline 5 & 45 & $\begin{array}{l}44 \\
(+19)\end{array}$ & $\begin{array}{l}51 \\
(+9)\end{array}$ & $\begin{array}{l}20 \\
(+13)\end{array}$ & $\begin{array}{l}19 \\
(+19)\end{array}$ & $\begin{array}{l}20 \\
(+17)\end{array}$ & $\begin{array}{l}30 \\
(+17)\end{array}$ & $\begin{array}{l}37 \\
(+6)\end{array}$ & $\begin{array}{l}36 \\
(+17)\end{array}$ & $\begin{array}{l}29 \\
(+10)\end{array}$ \\
\hline 6 & 60 & $\begin{array}{l}60 \\
(+20)\end{array}$ & $\begin{array}{l}52 \\
(+10)\end{array}$ & $\begin{array}{l}35 \\
(+12)\end{array}$ & $\begin{array}{l}24 \\
(+18)\end{array}$ & $\begin{array}{l}21 \\
(+18)\end{array}$ & $\begin{array}{l}37 \\
(+15)\end{array}$ & $\begin{array}{l}40 \\
(+6)\end{array}$ & $\begin{array}{l}44 \\
(+11)\end{array}$ & $\begin{array}{l}30 \\
(+9)\end{array}$ \\
\hline 7 & 120 & $\begin{array}{l}76 \\
(+8)\end{array}$ & $\begin{array}{l}62 \\
(+7)\end{array}$ & $\begin{array}{l}45 \\
(+5)\end{array}$ & $\begin{array}{l}40 \\
(+20)\end{array}$ & $\begin{array}{l}29 \\
(+17)\end{array}$ & $\begin{array}{l}54 \\
(+14)\end{array}$ & $\begin{array}{l}45 \\
(+4)\end{array}$ & $\begin{array}{l}58 \\
(+14)\end{array}$ & $\begin{array}{l}32 \\
(+14)\end{array}$ \\
\hline
\end{tabular}

Table 8: Reaction of benzaldehyde (3a) with indium propiophenone enolate in the CYTOS ${ }^{\mathrm{TM}}$ Labsystem (5a/6a in \%).

\begin{tabular}{|c|c|c|c|c|c|c|c|c|}
\hline \multirow{2}{*}{ Entry } & \multirow{2}{*}{$\begin{array}{l}\text { Flow rate } \\
{\left[\mathrm{mL} \min ^{-1}\right]}\end{array}$} & \multicolumn{2}{|c|}{$22^{\circ} \mathrm{C}$} & \multicolumn{2}{|c|}{$34{ }^{\circ} \mathrm{C}$} & \multicolumn{2}{|c|}{$47^{\circ} \mathrm{C}$} & \multirow{2}{*}{$\begin{array}{l}\text { Average rxn. } \\
\text { time [min] }\end{array}$} \\
\hline & & $5 a$ & $6 a$ & $5 a$ & $6 a$ & $5 a$ & $6 a$ & \\
\hline 1 & 1 & - & - & - & - & - & - & 60 \\
\hline 2 & 2 & 62 & 12 & 59 & 10 & 50 & 14 & 30 \\
\hline 3 & 3 & 63 & 14 & 58 & 14 & 48 & 12 & 20 \\
\hline 4 & 5 & 21 & 12 & 20 & 9 & 12 & 6 & 12 \\
\hline 5 & 9 & 20 & 8 & 22 & 6 & 25 & 5 & 6 \\
\hline
\end{tabular}




\section{Discussion}

The experimental results indicated that two diastereomeric tetrahydro-2 $\mathrm{H}$-pyran-2,4-diols were formed at $0{ }^{\circ} \mathrm{C}$ in the presence of gallium and at $25{ }^{\circ} \mathrm{C}$ with $\mathrm{Sn}(\mathrm{IV})$, but only one (i.e., 5a) at elevated temperature. Such finding is indicative of thermodynamic control in the reaction. In the first step, presumably a metal di-, tri- or tetraenolate is formed based on the ratio of enolate to metal chloride. Because in principle a metal dienolate is sufficient as the nucleophilic component, additional enolate ligands may simply act as "innocent bystander ligands" in the reaction cascade. Since we have been able to obtain $\mathbf{5 a}$ with $\mathrm{GaCl}_{3}$ in a diastereomerically pure form at $25{ }^{\circ} \mathrm{C}-$ although at low temperature a sizeable amount of $20 \%$ of a second diastereomer was formed - it is reasonable to assume a reversible formation of the metal-bound tetrahydro- $2 \mathrm{H}$-pyran2,4-diol. Under thermodynamic control all large substituents $\mathrm{R}$ (methyl, phenyl) are placed in the equatorial position which leads for all metal ions excluding Ga to only 1 out of 16 possible diastereoisomers.

To shed more light on the mechanism, DFT calculations were carried out using the Gaussian 09 program [44]. Gas-phase optimization of geometries was performed by using the B3LYP [45-47] method with Pople's split-valence 6-31G(d) basis set on $\mathrm{C}, \mathrm{H}, \mathrm{O}$ atoms and double- $\zeta$ quality basis set (LANL2DZ) [4850] containing Hay and Wadt's effective core potential (ECP) on hexa-coordinate indium [51] as implemented in Gaussian 09 owing to the predicted good results in our earlier work [30]. The remaining coordination sites of indium were occupied by two THF molecules. The minima and transition states of the calculated structures were verified by analyzing the harmonic vibrational frequencies, using analytical second derivatives. To predict the energies plausibly, as recommended for organometallic compounds, single point calculations with M06 functional [52] were performed using the same basis sets (Scheme 6).

Complexation of the metal enolate $\mathbf{E}$ with benzaldehyde (PhCHO) is followed by the exergonic first aldol addition showing a small activation barrier of $1.82 \mathrm{kcal} \mathrm{mol}^{-1}$ via a half-chair like transition state (TS-C-A1), which is in accord with the anti-selective aldol addition of titanium enolates [53,54]. TS-C-A1 leads to the formation of anti-aldolate A1, possessing $\Delta G_{\text {rel }}$ of $-6.60 \mathrm{kcal} \mathrm{mol}^{-1}$. In the next step, $\mathbf{A} \mathbf{1}$ is attacked by a second enolate at higher temperature via the bicyclic transition state TS-A1-A2 $\left(\Delta G_{\text {rel }}=4.18 \mathrm{kcal} \mathrm{mol}^{-1}\right)$ with a chair-chair conformation. In the last step, intramolecular cyclization with a relative TS energy of $1.22 \mathrm{kcal} \mathrm{mol}^{-1}$ (TSA2-A3) takes place, which furnishes the metal-bound hemiacetal in a boat conformation (A3) with a relative free energy of $-7.49 \mathrm{kcal} \mathrm{mol}^{-1}$. Hydrolysis of $\mathbf{A 3}$ provides tetrahydro- $2 \mathrm{H}$ pyran-2,4-diol 5a.

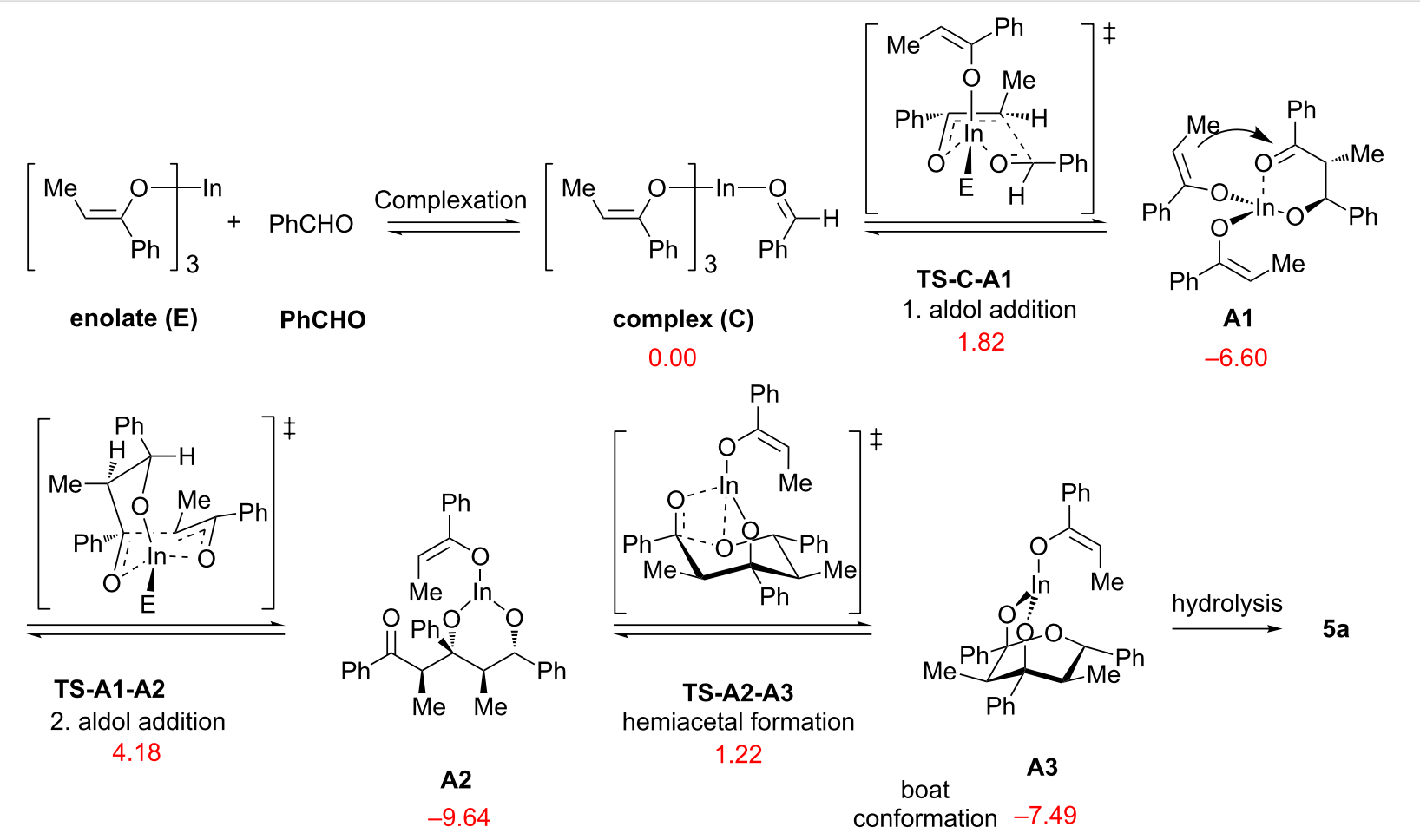

Scheme 6: DFT calculations on the formation of A3, hydrolysis of which provides 5a, at M06/6-31G(d)/LANL2DZ//B3LYP/6-31G(d)/LANL2DZ level $\left(\Delta G_{\mathrm{rel}}\right.$ with unscaled zpe are in $\left.\mathrm{kcal} \mathrm{mol}^{-1}\right)$. 
Computationally predicted $\mathbf{A} 2$ has a lower free energy than the hemiacetal A3, which is responsible for the formation of product 5a. This finding suggests that the hydrolysis occurs on the stage of $\mathbf{A 2}$ furnishing $\mathbf{A} \mathbf{2}_{\mathbf{O H}}$. Afterwards, intramolecular ring closure of $\mathbf{A} \mathbf{2}_{\mathbf{O H}}$ with a relative activation barrier of $23.8 \mathrm{kcal} \mathrm{mol}^{-1}$ leads to $\mathbf{5 a}$ in an exergonic process (Scheme 7). At higher temperature, the condensation product 6ac emerges from the dehydration of $\mathbf{6 a}$, taking place via an irreversible reaction, which is accountable for the decrease of the yield at higher temperatures.

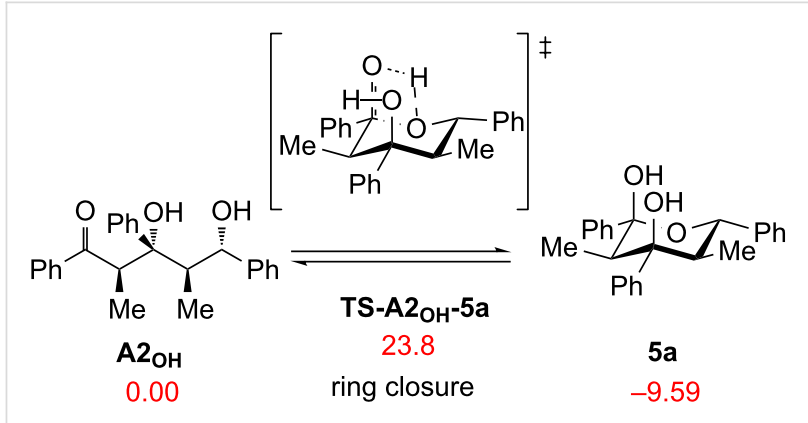

$$
\overbrace{\mathrm{Me}}^{\mathrm{OH}}
$$
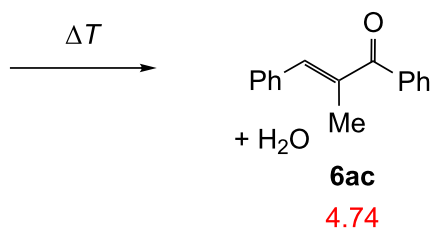

Scheme 7: The follow-up reactions of $\mathbf{A 2}$ OH and $\mathbf{6 a}$ at $\mathrm{M06} / 6-31 \mathrm{G}(\mathrm{d}) / /$ B3LYP/6-31G(d) level $\left(\Delta G_{\text {rel }}\right.$ with unscaled zpe are in $\left.\mathrm{kcal} \mathrm{mol}^{-1}\right)$.

The mechanism depicted in Scheme 6 is in agreement with the following set of requirements with regard to the metal center: it should (a) exhibit Lewis acidity, (b) be sufficiently electroposi- tive, and (c) display a sufficiently large ion radius so that the reaction cascade can take place in the periphery of the metal. The latter requirement is apparently prohibitive for a boron(III)mediated reaction because the ion radius of the $\mathrm{B}^{3+}$ ion is very small (25 pm). In the case of tin(II), a high yield of $6 \mathbf{a}$ (up to $90 \%$ ) was observed but formation of $\mathbf{5 a}$ was not detected which indicates a hindrance for the second aldol addition. Presumably due to the low charge density of the $\mathrm{Sn}^{2+}$ ions the second carbonyl function is not sufficiently activated for the last ketone-ketone-aldol step. For lanthanum and cerium and maybe even for tin(II) the size may cause problems since these ions are too big. The distance between the reactants is probably too large for a bond formation (Table 9).

In the case of 9-anthracenylaldehyde (3f) employing $\mathrm{Zr}$ or $\mathrm{Al}$, formation of $\mathbf{5 a}$, which was not observed in the presence of indium, is detected. Most likely the size of the anthracenyl moiety decreases the rate of the second aldol reaction or the hemiacetal formation, so that deprotonation and subsequently a retro-aldol reaction takes place (Scheme 8 ). The formation of a domino aldol product with two anthracenyl residues was not observed most probably due to the steric demand of the anthracenyl unit.

As illustrated in Scheme 8, the conversion of the aldehyde to the ketone moiety was also witnessed with benzaldehyde (3a) and 4-methoxybenzaldehyde (3d) in the reaction with 4'-fluoropropiophenone (1b) enolate and when reacting 4-methoxybenzaldehyde (3d) with propiophenone (1a) enolate. Here, there is also no interaction between the metal center and the aryl ring of the aldehyde possible. So, a competition between the second aldol or hemiacetal formation and the deprotonation should be

\begin{tabular}{|c|c|c|c|c|}
\hline Metal & $x^{a}$ & Ionic radius ${ }^{b}[p m]$ & Charge density $Z^{2} / r\left[\mathrm{e}^{2} \AA^{-1}\right]$ & Yield 5a [\%] \\
\hline $\mathrm{SnCl}_{2}$ & 1.72 & 102 (CN 2) & 3.92 & - \\
\hline $\mathrm{ZrCl}_{4}$ & 1.22 & $80(\mathrm{CN} 5)$ & 20.00 & 76 \\
\hline $\mathrm{SnCl}_{4}$ & 1.72 & 76 (CN 5) & 21.05 & 34 \\
\hline $\mathrm{TiCl}_{4}$ & 1.32 & 56 (CN 5) & 28.57 & 56 \\
\hline $\mathrm{BCl}_{3}$ & 2.01 & $25(\mathrm{CN} 4)$ & 36.00 & - \\
\hline $\mathrm{AlCl}_{3}$ & 1.47 & $53(\mathrm{CN} 4)$ & 16.98 & 52 \\
\hline $\mathrm{GaCl}_{3}$ & 1.82 & $61(\mathrm{CN} 4)$ & 14.80 & 93 \\
\hline $\mathrm{InCl}_{3}$ & 1.49 & $76(\mathrm{CN} 4)$ & 11.84 & 85 \\
\hline $\mathrm{LaCl}_{3}$ & 1.08 & 117 (CN 6) & 7.69 & - \\
\hline $\mathrm{CeCl}_{3}$ & 1.08 & 115 (CN 6) & 7.82 & - \\
\hline $\mathrm{Sc}(\mathrm{OTf})_{3}$ & 1.20 & $89(\mathrm{CN} 6)$ & 10.11 & - \\
\hline
\end{tabular}
considered.

${ }^{\mathrm{a}} \mathrm{X}$ : Electronegativity (According to Allred and Rochow). ${ }^{\mathrm{b}} \mathrm{CN}=$ Coordination number [55]. 


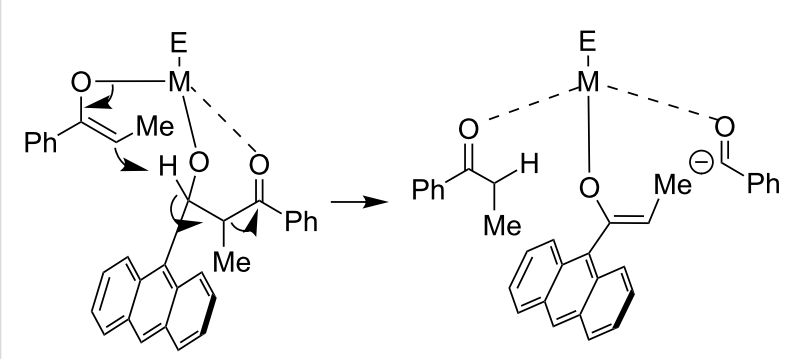

Scheme 8: Proposed mechanism for the formation of benzaldehyde in the reaction of 9-anthracenylaldehyde (3f) with $\mathrm{Zr}$ and $\mathrm{Al}$.

\section{Conclusion}

The present results demonstrate a domino aldol reaction working with several substrates and metals that is far superior to the other method with $\mathrm{TiCp}_{2}$ [20,22], which could only be realized with one single substrate resulting in a formal trimerization. The variations in the metal fragment are promising with regard to the development of an enantioselective version of the above reaction and further variations in the substrates. DFT calculations unveil the mechanism for the stereoselective formation of $\mathbf{5 a}$.

\section{Supporting Information}

Experimental section, copies of ${ }^{1} \mathrm{H}$ and ${ }^{13} \mathrm{C}$ NMR spectra of compounds, Cartesian coordinates and CIF files of $\mathbf{5 a}$ and $7 \mathbf{h}$.

\section{Supporting Information File 1}

Experimental section, copies of ${ }^{1} \mathrm{H}$ and ${ }^{13} \mathrm{C}$ NMR spectra of compounds and Cartesian coordinates.

[http://www.beilstein-journals.org/bjoc/content/ supplementary/1860-5397-12-80-S1.pdf]

\section{Supporting Information File 2 \\ CIF file of compound $\mathbf{5 a}$.}

[http://www.beilstein-journals.org/bjoc/content/ supplementary/1860-5397-12-80-S2.cif]

\section{Supporting Information File 3}

CIF file of compound $\mathbf{7 h}$.

[http://www.beilstein-journals.org/bjoc/content/ supplementary/1860-5397-12-80-S3.cif]

\section{Acknowledgements}

Support from the DFG (Graduiertenkolleg, SFB), Degussa AG and the Fonds der Chemischen Industrie is gratefully acknowledged. We thank Dr. Thomas Koy and Wolfgang Henn for valuable preparative work and helpful discussions in the early stage of this manuscript. We are indebted to the High-Performance-Computing (HPC) Linux Cluster HorUS of University of Siegen for computational support.

\section{References}

1. Wurtz, C. A. Bull. Soc. Chim. Fr. 1872, 17, 436-442.

2. Nielsen, A. T.; Houlihan, W. J. The Aldol Condensation. In Organic Reactions; Cope, A. C., Ed.; Wiley: New York, 1968; Vol. 16, pp $1 \mathrm{ff}$.

3. Mekelburger, H. B.; Wilcox, C. S. Formation of Enolates. In Comprehensive Organic Synthesis. Selectivity, Strategy, and Efficiency in Modern Organic Chemistry; Trost, B. M.; Fleming, I., Eds.; Pergamon Press: Oxford, 1991; Vol. 2, pp 99-131.

4. Heathcock, C. H. Modern Enolate Chemistry: Regio- and Stereoselective Formation of Enolates and the Consequence of Enolate Configuration on Subsequent Reactions. In Modern Synthetic Methods; Scheffold, R., Ed.; VHCA: Basel, 1992; Vol. 6, pp $1 \mathrm{ff}$.

5. Mahrwald, R. Aldol Reactions; Springer Science+Business Media B.V.: Heidelberg, 2009. doi:10.1007/978-1-4020-8701-1

6. Evans, D. A.; Fitch, D. M.; Smith, T. E.; Cee, V. J. J. Am. Chem. Soc. 2000, 112, 10033-10046. doi:10.1021/ja002356g

7. Crimmins, M. T.; Katz, J. D.; Washburn, D. G.; Allwein, S. P.; McAtee, L. F. J. Am. Chem. Soc. 2002, 124, 5661-5663. doi:10.1021/ja0262683

8. Tanaka, H.; Sawayama, A. M.; Wandless, T. J. J. Am. Chem. Soc. 2003, 125, 6864-6865. doi:10.1021/ja035429f

9. Song, H. Y.; Joo, J. M.; Kang, J. W.; Kim, D.-S.; Jung, C.-K.; Kwak, H. S.; Park, J. H.; Lee, E.; Hong, C. Y.; Jeong, S.; Jeon, K.; Park, J. H. J. Org. Chem. 2003, 68, 8080-8087. doi:10.1021/jo034930n

10. Kalesse, M.; Cordes, M.; Symkenberg, G.; Lu, H.-H. Nat. Prod. Rep. 2014, 31, 563-594. doi:10.1039/c3np70102f

11. Shiina, I. Chem. Rec. 2014, 14, 144-183. doi:10.1002/tcr.201300022

12. Mukaiyama, T.; Banno, K.; Narasaka, K. J. Am. Chem. Soc. 1974, 96, 7503-7509. doi:10.1021/ja00831a019

13. Mukaiyama, T. Org. React. 1982, 28, 203-331.

14. Braun, M. Formation of C-C- Bonds by Addition of Enolates to Carbonyl Groups. In Stereoselective Synthesis: C-C Bond Formation by Addition to $\mathrm{C}=\mathrm{O}, \mathrm{C}=\mathrm{N}$ and Reactions Involving Olefinic Double Bonds; Hoffmann, W.; Mulzer, J.; Schaumann, E.; Hoffmann, J., Eds.; Houben-Weyl, Methods of Organic Chemistry, Vol. E 21b; Thieme Verlag: Stuttgart, 1995; pp 1603-1666.

15. Machajewski, T. D.; Wong, C.-H. Angew. Chem., Int. Ed. 2000, 39, 1352-1375. doi:10.1002/(SICI)1521-3773(20000417)39:8<1352::AID-ANIE1352>3 $0 . \mathrm{CO} ; 2-\mathrm{J}$

16. Andrushko, V.; Andrushko, N., Eds. Stereoselective Synthesis of Drugs and Natural Products; John Wiley \& Sons: Hoboken, 2013; Vol. 1, pp 215-249.

17. Wang, X.; Meng, Q.; Nation, A. J.; Leighton, J. L. J. Am. Chem. Soc. 2002, 124, 10672-10673. doi:10.1021/ja027655f See for aldol reactions as a first step in a domino process.

18. Bazin, S.; Feray, L.; Siri, D.; Naubron, J.-V.; Bertrand, M. P. Chem. Commun. 2002, 2506-2507. doi:10.1039/B206695E See for aldol reactions as a second step in a domino process.

19. Davies, H. M. L.; Lian, Y. Acc. Chem. Res. 2012, 45, 923-935. doi:10.1021/ar300013t See for aldol reactions as a later step in a domino process.

20. Ghorai, M. K.; Halder, S.; Das, S. J. Org. Chem. 2015, 80, 9700-9712. doi:10.1021/acs.joc.5b01768 
21. Barba, F.; de la Fuente, J. L. J. Org. Chem. 1996, 61, 8662-8663. doi:10.1021/jo952158।

22. Yun, S.-S.; Suh, I.-H.; Choi, S.-S.; Lee, S. Chem. Lett. 1998, 27, 985-986. doi:10.1246/cl.1998.985

23. Ghosh, A. K.; Shevlin, M. The Development of Titanium Enolate-based Aldol Reactions. In Modern Aldol Reactions; Mahrwald, R., Ed.; Wiley-VCH: Weinheim, 2008; pp 63-125.

24. Kanno, K.-I.; Takahashi, T. Zr(IV) and Hf(IV) Lewis Acids. In Acid Catalysis in Modern Organic Synthesis; Yamamoto, H.; Ishihara, K., Eds.; Wiley-VCH: Weinheim, 2008; Vol. 2, pp 825-858.

25. Mukaiyama, T.; Matsuo, J.-I. Boron and silicon enolates in crossed aldol reaction. In Modern Aldol Reactions; Mahrwald, R., Ed.; Wiley-VCH: Weinheim, 2008; pp 127-160.

26. Renzetti, A.; Marrone, A.; Gérard, S.; Sapi, J.; Nakazawa, H.; Re, N.; Fontana, A. Phys. Chem. Chem. Phys. 2015, 17, 8964-8972. doi:10.1039/C4CP05412A

27. Dias, L. C.; Aguilar, A. M. Chem. Soc. Rev. 2008, 37, 451-469. doi:10.1039/B701081H

28. Donohoe, T. J. Contemp. Org. Synth. 1996, 3, 1-18. doi:10.1039/CO9960300001

29. Evans, D. A.; Janey, J. M.; Magomedov, N.; Tedrow, J. S. Angew. Chem., Int. Ed. 2001, 40, 1884-1888. doi:10.1002/1521-3773(20010518)40:10<1884::AID-ANIE1884>3.0.CO ;2-9

30. Cinar, M. E.; Schmittel, M. J. Org. Chem. 2015, 80, 8175-8182. doi:10.1021/acs.joc.5b01256 And references therein.

31. Dénès, F.; Pérez-Luna, A.; Chemla, F. Chem. Rev. 2010, 110, 2366-2447. doi:10.1021/cr800420x And references therein.

32. Schmittel, M.; Burghart, A.; Malisch, W.; Reising, J.; Söllner, R. J. Org. Chem. 1998, 63, 396-400. doi:10.1021/jo971650x

33. Schmittel, M.; Burghart, A.; Werner, H.; Laubender, M.; Söllner, R. J. Org. Chem. 1999, 64, 3077-3085. doi:10.1021/jo981793z

34. Schmittel, M.; Ghorai, M. K.; Haeuseler, A.; Henn, W.; Koy, T.; Söllner, R. Eur. J. Org. Chem. 1999, 2007-2010. doi:10.1002/(SICI)1099-0690(199909)1999:9<2007::AID-EJOC2007>3 .0.CO;2-2

35. Schmittel, M.; Ghorai, M. K. Synlett 2001, 1992-1994. doi:10.1055/s-2001-18766

36. Schmittel, M.; Haeuseler, A.; Nilges, T.; Pfitzner, A. Chem. Commun. 2003, 34-35. doi:10.1039/B209536J

37. Haeuseler, A.; Henn, W.; Schmittel, M. Synthesis 2003, 2576-2589. doi:10.1055/s-2003-42450

38. Kobayashi, S.; Hachiya, I. J. Org. Chem. 1994, 59, 3590-3596. doi:10.1021/jo00092a017

39. Cuperly, D.; Petrignet, J.; Crévisy, C.; Grée, R. Chem. - Eur. J. 2006, 12, 3261-3274. doi:10.1002/chem.200501555

40. CCDC 1470044 contains the supplementary crystallographic data for this paper. The data can be obtained free of charge from The Cambridge Crystallographic Data Centre via http://www.ccdc.cam.ac.uk/data_request/cif

41. Giorgi, G.; Arroyo, F. J.; López-Alvarado, P.; Menéndez, J. C. Tetrahedron 2011, 67, 5582-5589. doi:10.1016/j.tet.2011.05.115

42. Schmittel, M.; Söllner, R.; Drauz, K.; Günther, K.

Tetrahydropyran-2,4-diole, Verfahren zu deren Herstellung und Verwendung. Deutsches Patent- und Markenamt DE 19911198 A1, May 11, 2000.
43. CCDC 1470045 contains the supplementary crystallographic data for this paper. The data can be obtained free of charge from The Cambridge Crystallographic Data Centre via http://www.ccdc.cam.ac.uk/data_request/cif

44. Gaussian 09, Revision D.01; Gaussian, Inc.: Wallingford CT, 2010.

45. Becke, A. D. J. Chem. Phys. 1993, 98, 1372-1377. doi:10.1063/1.464304

46. Becke, A. D. J. Chem. Phys. 1993, 98, 5648-5652. doi:10.1063/1.464913

47. Lee, C.; Yang, W.; Parr, R. G. Phys. Rev. B 1988, 37, 785-789. doi:10.1103/PhysRevB.37.785

48. Hay, P. J.; Wadt, W. R. J. Chem. Phys. 1985, 82, 270-283. doi:10.1063/1.448799

49. Wadt, W. R.; Hay, P. J. J. Chem. Phys. 1985, 82, 284-298. doi:10.1063/1.448800

50. Hay, P. J.; Wadt, W. R. J. Chem. Phys. 1985, 82, 299-310. doi:10.1063/1.448975

51. Wells, R. L.; Kher, S. S.; Baldwin, R. A.; White, P. S. Polyhedron 1994, 13, 2731-2735. doi:10.1016/S0277-5387(00)83430-0 See for: Indium trichloride crystallizes from $\mathrm{THF}$ as $\mathrm{InCl}_{3}(\mathrm{THF})_{3}$.

52. Zhao, Y.; Truhlar, D. G. Theor. Chem. Acc. 2008, 120, 215-241. doi:10.1007/s00214-007-0310-x

53. Annunziata, R.; Cinquini, M.; Cozzi, F.; Borgia, A. L. J. Org. Chem. 1992, 57, 6339-6342. doi:10.1021/jo00049a053

54. Kanemasa, S.; Mori, T.; Tatsukawa, A. Tetrahedron Lett. 1993, 51, 8293-8296. doi:10.1016/S0040-4039(00)61414-4

55. Huheey, J. E.; Keiter, E. A.; Keiter, R. L. Inorganic Chemistry: Principles of Structure and Reactivity, 4th ed.; Harper Collins: New York, 1993.

\section{License and Terms}

This is an Open Access article under the terms of the Creative Commons Attribution License (http://creativecommons.org/licenses/by/2.0), which permits unrestricted use, distribution, and reproduction in any medium, provided the original work is properly cited.

The license is subject to the Beilstein Journal of Organic Chemistry terms and conditions:

(http://www.beilstein-journals.org/bjoc)

The definitive version of this article is the electronic one which can be found at: doi:10.3762/bjoc. 12.80 